\title{
Effect of Microcredit on Profit Efficiency of Small-Scale Poultry Farmers Oyo State, Nigeria
}

\author{
Ronke Victoria ORIMOGUNJE*, Ayodeji Sunday OGUNLEYE, Ayodeji Damilola KEHINDE \\ Department of Agricultural Economics, Obafemi Awolowo University, Ile-Ife, Osun State, Nigeria
}

\begin{abstract}
This study investigated the effect of microcredit on profit efficiency of small-scale poultry farmers in Oyo State. Multistage sampling procedure was used to select two hundred poultry farmers for the study. Data collected were analysed using descriptive statistics, Heckman selection model, stochastic frontier and Tobit models. Result from descriptive statistics showed that men $(78 \%)$ are predominantly involved in poultry production. The average age of poultry farmers in the area of study is approximately 43 years. Most of the farmers are married (77.5\%) and literate (80.5\%). Furthermore, most of the respondents $(73.5 \%)$ had access to microcredit with $87.5 \%$ belonging to one farmer's association or the other. Heckman two-stage selection model revealed that membership of cooperative/farmer's association and contact with extension agent are the significant factors influencing farmer's access to microcredit. The second stage of the model reveals that age, years of education, household size, years of farming experience, distance to source of microcredit, timeliness of microcredit and stock size are the significant factors influencing the amount of microcredit obtained by farmers. Results obtained from the stochastic frontier model showed that smallholder poultry farmers had an average profit efficiency of $54.0 \%$ in poultry production. Furthermore, the Tobit model (Model 1) results revealed that amount of microcredit, distance to source of microcredit, interest rate and loan repayment period significantly influenced farmer's profit efficiency while in the second model, years of formal education, poultry farming experience and membership of cooperative/farmer's association influenced farmer's profit efficiency. The results of two-side censored Tobit model suggest that microcredit variables are the most favourable variables for line of action. This suggested that policy makers should ensure that microcredit available through the agricultural credit programmes get to the needy farmers.
\end{abstract}

Key words: microcredit, profit efficiency, poultry, small scale farming, Oyo State

\section{INTRODUCTION}

Poultry contributes to family nutrition through the supply of overall annual protein of about $15 \%$ with an approximate amount of $1.3 \mathrm{~kg}$ of poultry consumption per person per annum (Ologbon and Ambali, 2012). The Nigerian poultry industry was estimated at $\$ 80$ billion (\$600 million) and is comprised of about 165 million birds, which produced 650,000 metric tonnes of eggs and 290,000 metric tonnes of poultry meat in 2013 (SAHEL, 2015). According to Akintunde and Adeoti (2014) and Ewubare and Ozar (2018), poultry production in Nigeria is dominated by small scale farmers who on the aggregate produce about $90 \%$ of the total national poultry production and individually rear less than 3,000 bird which brings economic returns within a period of three months. Despite this great prospect in poultry production, small scale poultry farmers in Nigeria continue to experience serious challenges in poultry enterprise which has brought about low productivity and efficiency in this sector. One of the fundamental obstacles facing small scale poultry farmers in Southwestern Nigeria especially Oyo State is the lack of access to microcredit. According to literature, only $4 \%$ of 
the poultry farms in Oyo State had access to about 3.1 to \#3.5 million funding per year, hence most poultry farms operated below secured credit level (Olagunju, 2010). This in turn limit the amount of credit facilities available to obtain essential items such as drugs and vaccines, high quality and sufficient feeds, hybrid chicks, cages and feeding troughs. The limited access to fund by majority of these small-scale poultry farmers may be generally linked with their low level of farm income and collateral securities which ultimately leads to low effciciency (Akanni, 2007; Olagunju and Babatunde, 2011).

Efficiency can be measured by classical and frontier method. In poultry production, the classical method compares the number of meat or eggs produced by birds (output) to amount used in raising the birds (input) while the frontier approach indicates that efficient firms are those operating on the production frontier and generate more profits. The quantity by which a farm lies beneath its production frontier is the measure of inefficiency and losses profits (Adesiyan, 2014). Profit efficiency is defined as the ability of a farm to achieve the highest possible profit given the prices and levels of fixed factors of that farm, and profit inefficiency in this context is defined as loss of profit or revenue for not operating on the frontier (Tsue et al., 2012). The profit efficiency can be expressed as the ratio of predicted actual profit to the predicted maximum profit for a best-practiced farmer. Hence, a farm is more profit efficient than another when it makes highest feasible profit by proficient utilization of available resources. However, the studies of Agbaeze and Onwuka (2014) and Oshinowo et al. (2017) have posited that farmers often experience difficulty in accessing credit from formal financial institutions hence, access to microcredit could be a critical factor to increase efficiency among farmers. In order to seal the substantial gap in the financial delivery system, microcredit schemes were introduced to Nigeria in the 1990s. Microcredit scheme is the disbursement of small, low interest and non-collaterised credits to the poor, relying on communal collateral and joint liability. Microcredit helps in boosting agricultural production, stimulating economic development, improving the standard of living of the populace as well as ameliorating the inadequacies of the formal lending system (Prince et al., 2014). Microcredit can be differentiated from the standard loan in the small size of loan supplied and the savings collected, distribution of loan without collateral and the simplicity of the operations.

There have been several studies conducted on microcredit and profit efficiency of farmers. Tijani et al. (2006) and Bamiro et al. (2013) in their separate studies found out that access to credit has an inverse relationship with the profit efficiency of poultry farmers and concluded that profit efficiency can be enhanced with prudent disbursement of accessible funds. Akaps and Odoemenem (2018) and Tibi and Adaiigho (2015) emphasized that credit effect on productivity was greatest for household size. This implies that to increase small scale poultry farmer's productivity exploiting of family labour was the most desirable. Haile (2014) indicated that cost of hired labour and land area had positive influence on Sidama's coffee farmers profit levels while capital and cost of labour have negative effect on profitability with mean profit efficiency of $57 \%$ which means that there was a $43 \%$ profit loss. In spite of all these studies reviewed, none of these researches identified the leading and important variables between the socioeconomic characteristics of the farmers and the microcredit variables affecting profit efficiency of smallscale farmers in Oyo state. This study tackled this problem by estimating a stochastic profit frontier (first stage analysis) which provides a basis for measuring farm specific profit efficiency and by estimating two-side censored Tobit model (a second stage analysis) to identify key variables that affect profit efficiency and hence, provide policy guidelines. The objectives of this study are to describe the socio-economic characteristics of the small-scale poultry farmers, profile the sources of microcredit accessible to the farmers in the study area, determine the factors influencing access to microcredit and amount/size of microcredit obtained by the poultry farmers and evaluate the effect of microcredit on the profit efficiency of small-scale poultry farmers.

\section{MATERIALS AND METHODS}

\section{The study area}

The study was conducted in Oyo State Nigeria, latitude $7^{\circ}$ $51^{\prime} \mathrm{N}$ and $9.25^{\prime \prime} \mathrm{N}$ and longitude $3^{\circ} 55^{\prime} \mathrm{E}$ and $52.50^{\prime \prime} \mathrm{E}$. It is surrounded in the North by Kwara state, in the East by Osun State and by Kwara State, in the South by Ogun State and in the West by Benin Republic. It has a total population of about 6 million people and majority of the farmers in this state are small scale farmers. Food crops grown include yam, cassava, cocoyam, maize, rice, cowpea etc. Also, livestock such as rabbit, pig, cattle, sheep, goat and poultry are reared in the state. Poultry business is one of the prevalent agribusiness in Oyo state. It serves as a source of income, food security, employment and wealth creation.

\section{Sampling procedure}

Primary data were collected from small scale poultry farmers through structured questionnaires administered to the target samples of 200 poultry farms. A multi-stage sampling procedure was employed. The first stage involved purposive selection of two Agricultural Development Zones from the four Agricultural Development Zones in Oyo state. They are Ibadan and Ogbomoso Zones. The second stage involved a purposive selection of five Local Government Areas (Ido, Egbeda, Lagelu, Akinyele and Oluyole) in Ibadan Zones and all the five Local Government Areas (Surulere, Orire, Ogo Oluwa, Ogbomosho North and Ogbomosho South) in Ogbomosho Zones based on the information derived from the Poultry Association of Nigeria, Oyo State chapter. At the final stage, simple random technique was employed to select 20 small scale poultry farmers from each of the Local Government Areas. In total, 200 poultry farmers were selected for the study. 


\section{Analytical technique}

Descriptive statistics, Heckman selection model, stochastic profit frontier function and tobit model were used to analyse the collected data.

\section{Descriptive statistics}

Descriptive statistics (mean and percentages) were used to describe the socioeconomic characteristics of smallholder poultry farmers and the sources of microcredit accessible to farmers.

\section{Heckman Selection Model}

Heckman selection model is a two-step statistical procedure that tackles simultaneity problems and correct selection bias. The Heckman model was employed firstly to analyse the selection of small-scale poultry farmers access to microcredit while the second stage analysed factor influencing the $Y_{i}=\beta_{0}+\beta_{1} X_{1}+\beta_{2} X_{2}+\beta_{3} X_{3}+, \ldots,+\beta_{9} X_{9}+\varepsilon_{\text {cess }}$ to microcredit was evaluated by means of a Probit maximum likelihood and is expressed as

The dependent variable is:

$\mathrm{Y}_{1}=0$ for farmers that do not have access and 1 for farmers that have access.

The explanatory variables are:

$X_{1}=$ Age of the farmer (years), $X_{2}=\operatorname{Sex}$ (male $=1$. otherwise $=0), X_{3}=$ Education (years in school). $X_{4}$ $=$ Household size of farmer (number of people), $X_{5}=$ Experience in poultry business (years), $X_{6}=$ Physical distance from farmer resident to lending source ( 1 is $\geq 15 \mathrm{~km}$ and $<15 \mathrm{~km}$ otherwise), $X_{7}=$ Membership of social group (1 for member and 0 otherwise), $X_{8}$ $=$ Number of times in contact with an extension agent in a month, $X_{9}=$ Timeliness of loan $(1=$ Timely, 0 otherwise), $\varepsilon=$ Error term.

For the second stage, to examine the factors affecting size/amount of microcredit obtained by farmers that have access to microcredit $(Z=1)$ the equation is expressed as:

$Z_{i}=\Phi_{0}+\Phi_{1} \lambda_{i}+\Phi_{2} \lambda_{2}+\Phi_{3} \lambda_{3}+, \ldots,+\Phi_{10} \lambda_{i 0}+\varepsilon$

The dependent variable is:

$\mathrm{Z}_{1}=$ Size/Amount of microcredit borrowed by a poultry farmer ( $)$.

The explanatory variables are:

$\lambda_{i}=$ Age of the farmer (years), $\lambda_{2}=\operatorname{Sex}$ (male $=1$, otherwise $=0), \lambda_{3}=$ Education (years in school), $\lambda_{4}=$ Household size of farmer (number), $\lambda_{5}=$ Experience in poultry business (years), $\lambda_{6}=$ Physical distance from farmer resident to lending source ( 1 is $\geq 15 \mathrm{~km}$ and $<15 \mathrm{~km}$ otherwise), $\lambda_{7}=$ Membership of social group (1 for member and 0 otherwise), $\lambda_{8}=$ Interest rate ( $), \lambda_{9}=$ Timeliness of loan (1= Timely, 0 otherwise), $\lambda_{i 0}=$ Average number of stock of birds as a proxy for farm size (Hectare), $\varepsilon=$ Error term.

\section{Stochastic profit frontier function - first stage analysis}

The profit function approach conjoins the concepts of allocative and technical efficiency in the profit function and any errors in the production determination are presumed to result into lower income or profits for the farmers (Bamiro et al., 2013). Profit efficiency is the capability of a farm to attain highest feasible profit taken into account the prices and levels of fixed factors of that farm while profit inefficiency is the loss of profit as a result of not operating on the frontier (Tijani et al., 2006). The Stochastic Frontier Analysis (SFA) is an econometric frontier approach which identifies the connection between output and input levels and breaks the error term into two components: (1) a random error (2) an inefficiency component. The random error is the traditional normal error term with null mean and a constant variance and it also follows a symmetric distribution while the inefficiency component is presumed to follow an asymmetric distribution and it is indicated as truncated normal, halfnormal, exponential or two-parameter gamma distribution. The advantage of this model is that, it allows the estimation of farm specific efficiency scores and the factors explaining the efficiency differentials among farmers in a single stage estimation procedure. This analytical tool was used to determine the effect of access to microcredit on the profit efficiency of the respondent.

The stochastic profit function is defined as

$p_{i}=f\left(P_{i j}, Z_{k j}\right) \exp \left(V_{i-} U_{i}\right) i=1,2, . . n$

Where:

$\pi_{i}=$ normalized profit of the $\mathrm{j}^{\text {th }}$ farm, $\mathrm{P}_{\mathrm{ij}}=$ price of $\mathrm{j}^{\text {th }}$ variable input faced by the $\mathrm{i}^{\text {th }}$ farm divided by output price, $\mathrm{Z}_{\mathrm{ik}}=$ level of the $\mathrm{k}^{\text {th }}$ fixed factor on the $\mathrm{i}^{\text {th }}$ farm, $\mathrm{V}_{\mathrm{i}}=$ random error, $\mathrm{U}_{\mathrm{i}}$ = profit inefficiency effects, $\mathrm{i}=1 \ldots \ldots, \mathrm{n}=$ number of farm sample.

The explicit Cobb-Douglas functional form for the poultry farmers in the study area is:

$\operatorname{Inp}=\operatorname{Inb}_{0}+b_{1} \operatorname{InZ}_{1 \mathrm{i}}+\mathrm{b}_{2} \operatorname{InP}_{1 \mathrm{i}}+\mathrm{b}_{3} \operatorname{InP}_{2 \mathrm{i}}+\mathrm{b}_{4} \operatorname{InP}_{3 \mathrm{i}}+\mathrm{b}_{5} \operatorname{InP}_{4 \mathrm{i}}+\mathrm{b}_{6} \operatorname{InP}_{5 \mathrm{i}}+\mathrm{V}_{\mathrm{i}}(4)$

Where; $\pi=$ Normalized profit, $Z_{i}=$ Average price of fixed inputs $(\mathrm{N}), \mathrm{P}_{1}=$ Average price of stock of birds $(\mathrm{N}), \mathrm{P}_{2}=$ Average price of feed intake ( $), \mathrm{P}_{3}$ Average price of labour such as family + hired in man-days $(\mathrm{N}), \mathrm{P}_{4=}$ Average price of 
water per litre ( $), P_{5}$ Average price of other expenses such as cost of drugs and transportation ( $), \beta_{\mathrm{o}}=$ Constant term, $\beta_{1}=$ parameters to be estimated.

\section{Tobit regression model - second stage analysis}

In order to determine the effect of microcredit and the sources of efficiency, profit efficiency estimated from stochastic profit frontier function in the first stage are regressed on poultry farmer's socio-economic characteristics and microcredit variables in three separate equations (Model I, II and III) using Tobit model. The main goal of the secondstage analysis is to know the major variables that affect profit efficiency in the study area and to show the relationship between these variables and efficiency. Habitual view about efficiency in the literature is that tobit model can determine the characteristics of efficiency distribution measures and hence, provide valid policy guidelines (De Young and Hassan, 1998; Nor and Mohamad, 2011). Since the estimated profit efficiency level (dependent variable) is bounded between 0 and 1 therefore, Tobit model with two-side censoring will be an appropriate theoretical specification. Profit efficiency scores estimated in the first stage are used as the dependent variables in the second stage of censored Tobit model so as to give room for the range of efficiency values ( 0 to 1 ).

The model is written as follows:

$Y_{i}=X_{i} \beta+\varepsilon_{i}$

Where $Y_{i}$ is the profit efficiency score and the observed value of efficiency scores is given as:

$$
\begin{aligned}
Y_{i} & =0 \text { if } Y_{i} \leq 0 \\
& =Y_{i}^{*} \text { if } 0<Y_{i}^{*}<100 \\
& =100 \text { if } Y_{i} \geq 100
\end{aligned}
$$

The definitions of independent variable are: $\mathrm{X}_{1}=$ sex (male $=1$, female $=0$ ); $X_{2}=$ access to micro credit (if yes $=1,0=$ if no); $X_{3}=$ Household size (number of people in the house); $X_{4}$ = Age (Years); $\mathrm{X}_{5}=$ Year of Education (number of years spent in school); $\mathrm{X}_{6}=$ Amount of Microcredit ( $) ; \mathrm{X}_{7}=$ Farming experience (Years); $\mathrm{X}_{8}=$ Interest rate $(\%) ; \mathrm{X}_{9}=$ loan repayment period (days); $\mathrm{X}_{10}=$ Main occupation ( $1=$ if the respondent engages in farming; $0=$ if otherwise); $\mathrm{X}_{11}=$ Distances to micro-credit sources $(\mathrm{Km}) ; \mathrm{X}_{12}=$ membership of Microcredit groups (if yes $=1,0=$ if no); $\mathrm{X}_{13}=$ Timeliness (timely). The rationale behind the inclusion of the explanatory variables in the model was based on the review of literature.

\section{RESULTS AND DISCUSSION}

\section{Socioeconomic characteristics of small-scale poultry farmers}

The socio-economic characteristics of small-scale poultry farmers are presented in Table 1 . The majority (78\%) of the sampled farmers are male. Gender stereotype in poultry production could probably be an implication of the rigor tasks and energy requirement of its operations since women are usually perceived lethargy when compared to their male counterparts. The average age of poultry farmers in the area of study is 43 years. This result is in support of the findings of Tijani et al. (2006) and Gbigbi (2017) who reported similar results in their different studies on poultry production in Nigeria. Poultry production in the study area is characterized with high level of education as more than half (53.50\%) of the farmers have post-secondary education. Educational levels of farmers can influence how they search for and process information on the available credit opportunities to improve their level of farm profit. Most (54\%) of the sampled farmers had 8 persons or less in their households with an average farmer having 5.00 members. Larger household size may reduce farm profit as microcredit accessed may be diverted for family consumption. Majority (59\%) of the sampled farmers are part-time poultry farmers. This implied that farmers in the study area also engage in other work from which they generate additional income. Most (87.50\%) of the sampled farmers belong to cooperative/farmer's association. This result is supported by the findings of Adeyonu et al. (2017) who reported a positive relationship between membership of an association and access to credit. The result also indicated that $33.50 \%$ of the farmers did not subscribe to any microcredit sources, they finance their poultry farming activities through personal savings while only $15.00 \%$ sourced funds from cooperative societies. However, $4.50 \%$ of the respondents could procure microcredit from banks as a result of high interest rate, shorter loan repayment period and stringent procedures of the operations. About $29.50 \%$ of the sampled poultry farmers combined multiple sources of microcredit for their poultry businesses when there was credit rationing. Majority (38.50\%) of the sampled farmers that have access to microcredit are able to obtain limited amount of microcredit between $\$ 10,000.00$ - $\$ 500,000.00$. The minimum and maximum size of flock in the area of study is 150 and 2500 respectively. This also implied that poultry farmers in the study area were small scale farmers.

Table 1: Distribution of socioeconomic characteristics of poultry farmers in Oyo State

\begin{tabular}{|l|c|c|}
\hline & Frequency & Percentage \\
\hline Sex & & \\
\hline Male & 156 & 78.00 \\
\hline Female & 44 & 22.00 \\
\hline Age & & \\
\hline$\leq 30$ & 20 & 10.00 \\
\hline $31-40$ & 66 & 33.00 \\
\hline $41-50$ & 73 & 36.50 \\
\hline$>50$ & 41 & 21.50 \\
\hline Mean & 43.02 & \\
\hline Years of education & & \\
\hline No Education & 39 & 19.50 \\
\hline $1-6$ & 13 & 6.50 \\
\hline $7-12$ & 42 & 21.00 \\
\hline$>12$ & 106 & 53.00 \\
\hline Mean & 11.33 & \\
\hline
\end{tabular}




\begin{tabular}{|c|c|c|}
\hline \multicolumn{3}{|l|}{ Household size } \\
\hline $1-4$ & 80 & 40.00 \\
\hline $5-8$ & 107 & 53.50 \\
\hline$>9$ & 13 & 6.50 \\
\hline Mean & 5.00 & \\
\hline \multicolumn{3}{|l|}{ Major occupation } \\
\hline Crop farming & 24 & 12.00 \\
\hline Poultry farming & 82 & 41.00 \\
\hline Civil service & 37 & 18.50 \\
\hline Private business & 24 & 12.00 \\
\hline Artisan & 13 & 6.50 \\
\hline Trading & 20 & 10.00 \\
\hline \multicolumn{3}{|l|}{ Membership } \\
\hline Membership & 175 & 87.50 \\
\hline Non-member & 25 & 12.50 \\
\hline \multicolumn{3}{|l|}{ Microcredit Access } \\
\hline Access & 133 & 66.50 \\
\hline No access & 67 & 33.50 \\
\hline \multicolumn{3}{|l|}{ Sources of microcredit } \\
\hline Personal saving & 67 & 33.50 \\
\hline Cooperative & 30 & 15.00 \\
\hline Friends/family & 25 & 12.50 \\
\hline Money lender & 10 & 5.00 \\
\hline Banks & 9 & 4.50 \\
\hline cooperative and friends & 5 & 2.50 \\
\hline $\begin{array}{l}\text { Cooperative and } \\
\text { microfinance }\end{array}$ & 10 & 5.00 \\
\hline Microfinance and friends & 10 & 5.00 \\
\hline $\begin{array}{l}\text { Microfinance, friends and } \\
\text { cooperative }\end{array}$ & 9 & 4.50 \\
\hline Others & 25 & 12.50 \\
\hline \multicolumn{3}{|l|}{ Amount of microcredit } \\
\hline $\begin{array}{l}\text { No microcredit (personal } \\
\text { savings) }\end{array}$ & 67 & 33.50 \\
\hline$\leq \$ 100,000.00$ & 24 & 12.00 \\
\hline$\$ 110,000.00-\$ 500,000.00$ & 77 & 38.50 \\
\hline$\$ 510,000.00-\$ 1,000,000.00$ & 17 & 8.50 \\
\hline Above $1,000,000.00$ & 13 & 7.50 \\
\hline \multicolumn{3}{|l|}{ Flock size } \\
\hline$>500$ & 90 & 45.00 \\
\hline $501-1000$ & 84 & 42.00 \\
\hline $1001-1500$ & 13 & 6.50 \\
\hline$>1500$ & 13 & 6.50 \\
\hline
\end{tabular}

Source: Field survey (2019)

\section{Factors influencing access and amount of microcredit}

Table 2 reveals the results of the Heckman estimation by showing the coefficients of the factors that influenced microcredit access and amount of microcredit obtained by small scale poultry farmers. The Wald $\chi^{2}$ test value is 43.43 and significant at $1 \%$ level of significance which signify that the correlation between the disturbance error terms is equal to zero. Also, the inverse Mills ratio (IMR) value is -37.77 and was significant at 5\% level which confirms the appropriateness of the use of Heckman selection model as the use of OLS model would have resulted in biased estimates. The results show that the probability of poultry farmers accessing microcredit is greatly influenced by membership of

cooperative/farmer's association and contact with an extension agent. Poultry farmers are more likely to access microcredit if the farmer is a member of an association. However, the amount of microcredit received shows a negative relationship with membership of an association although the result is not significant the possible explanation could be that the amount of microcredit received is not only a function of being a member of an association but It is largely determine by the amount of savings that a member has with the association because most association that give microcredit to their members usually use the amount of savings that individual member has to determine the amount of microcredit extend to them. This result is in line with the findings of Anyiro (2015). In the same line, farmers that have regular contact with an extension agent are also more likely to access microcredit than their counterparts. This is actually true because extension services administer crucial information concerning agricultural credit, new technologies among others. This result agrees with Ibrahim and Bauer (2013) and Anang et al. (2015) findings.

The estimates of the second stage of the Heckman analysis reveals that age, year of education, household size, farming experience, distance to the sources of microcredit, timeliness of microcredit and stock size were the only significant factors influencing the size/amount of microcredit obtained by small scale poultry farmers. The coefficients of age, year of education and farming experience were positive and significant which signifies that farmers who are older, educated and have more years of experience in poultry farming can be trusted with larger amount of microcredit than younger farmers who have little experienced, lesser responsibilities and little or no education. Distance (being $\geq 15 \mathrm{~km}$ ) has a negative and significant impact on the amount of loan obtained. This suggests that if the distance from farmer's residence to microcredit source is farther than $15 \mathrm{~km}$, the amount of microcredit obtained will be little. This shows the behavioural aspect of the lending institutions because they believe that they can easily gather more information about farmers in their locality and also trust them to some extent with larger amount of microcredit than farmers outside their communities. This result contradicts the finding of Samuel (2017) who argues that for any additional kilometre travelled by farmers to borrow credit, loan amount increases. Poultry farmers receive lower amount of microcredit if they have larger household members. Lending institutions believe that farmers with larger household size may divert money borrowed for poultry production to cater for the need of the family. This result is corroborated by the findings of Enimu et al. (2018) that large family size reduces the borrowing capacity of smallholder farmers. The coefficients of timeliness and stock of birds were positive and significant. The higher the amount of microcredit, the longer time it takes the financial institution for investigations before releasing substantial amount of loan to their clients. The coefficient of stock of birds suggests that an increase in the size of stock will result in an increase in the amount of microcredit that poultry farmers will obtain since larger stock of birds requires more financial obligations in terms of running capital for the poultry business to be successful. 
Table 2: Determinants of access to microcredit and size/ amount of microcredit

\begin{tabular}{|c|c|c|c|c|}
\hline \multirow[b]{2}{*}{ Variables } & \multicolumn{2}{|c|}{$\begin{array}{c}\text { Access to } \\
\text { microcredit }\end{array}$} & \multicolumn{2}{|c|}{$\begin{array}{l}\text { Amount of } \\
\text { microcredit }\end{array}$} \\
\hline & Coefficients & t-ratio & Coefficients & t-ratio \\
\hline Age (years) & $\begin{array}{c}0.001 \\
(0.013)\end{array}$ & 0.11 & $\begin{array}{l}1.838^{\star *} \\
(0.785)\end{array}$ & 2.34 \\
\hline $\begin{array}{l}\text { Education } \\
\text { (years) }\end{array}$ & $\begin{array}{l}-0.009 \\
(0.015)\end{array}$ & -0.61 & $\begin{array}{l}2.377^{* *} \\
(0.997)\end{array}$ & 2.38 \\
\hline $\begin{array}{l}\text { Household } \\
\text { size (number) }\end{array}$ & $\begin{array}{c}0.064 \\
(0.050)\end{array}$ & 1.28 & $\begin{array}{c}-6.255^{\star *} \\
(2.841)\end{array}$ & -2.19 \\
\hline Sex (male) & $\begin{array}{l}-0.106 \\
(0.252)\end{array}$ & -0.42 & $\begin{array}{c}16.587 \\
(13.005)\end{array}$ & 1.28 \\
\hline $\begin{array}{l}\text { Farming } \\
\text { experience } \\
\text { (years) }\end{array}$ & $\begin{array}{c}0.023 \\
(0.021)\end{array}$ & 1.16 & $\begin{array}{l}3.062^{\star \star} \\
(1.377)\end{array}$ & 2.22 \\
\hline $\begin{array}{l}\text { Distance }(\geq \\
15 \mathrm{~km})\end{array}$ & $\begin{array}{l}-0.081 \\
(0.225)\end{array}$ & -0.36 & $\begin{array}{c}-34.414^{* * *} \\
(12.630)\end{array}$ & -2.72 \\
\hline $\begin{array}{l}\text { Membership } \\
\text { (member) }\end{array}$ & $\begin{array}{c}1.157^{* * *} \\
(0.336)\end{array}$ & 3.44 & $\begin{array}{l}-35.013 \\
(38.469)\end{array}$ & -0.91 \\
\hline $\begin{array}{l}\text { Timeliness } \\
\text { (timely) }\end{array}$ & $\begin{array}{c}0.115 \\
(0.212)\end{array}$ & 0.54 & $\begin{array}{c}46.941^{\star * *} \\
(13.542)\end{array}$ & 3.47 \\
\hline $\begin{array}{l}\text { Access to } \\
\text { extension (yes) }\end{array}$ & $\begin{array}{l}1.101^{* *} \\
(0.561)\end{array}$ & 1.96 & - & - \\
\hline $\begin{array}{l}\text { Stock size (no } \\
\text { of birds) }\end{array}$ & - & - & $\begin{array}{l}0.024^{* *} \\
(0.011)\end{array}$ & 2.31 \\
\hline $\begin{array}{l}\text { Interest rate } \\
(\%)\end{array}$ & - & - & $\begin{array}{c}0.438 \\
(1.089) \\
\end{array}$ & 0.40 \\
\hline IMR & - & - & $\begin{array}{c}-37.768^{\star *} \\
(17.186)\end{array}$ & -2.197 \\
\hline Constant & $\begin{array}{c}-1.176^{\star *} \\
(0.603)\end{array}$ & -1.96 & $\begin{array}{l}-32.698 \\
(49.618)\end{array}$ & -0.66 \\
\hline
\end{tabular}

Source: Data Analysis (2019). ${ }^{*}{ }^{* *},{ }^{* *}$ indicate statistical significance at the $10 \%, 5 \%$ and $1 \%$ alpha levels, respectively. Figures in parentheses are the robust standard errors.

Number of obs $=200-$ selected (130) Non-selected (70); Wald chi2(10) $=$

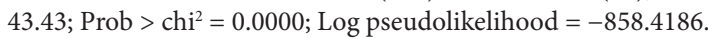

\section{Maximum likelihood values of the stochastic frontier model}

The maximum likelihood estimates (MLE) of the translog stochastic frontier profit function model was obtained using Frontier 4.1c package. The result presented in Table 3 shows that the farm profit efficiencies range from 0.08 to 0.90 . The mean efficiency estimate among poultry farmers was 0.54. This implies that poultry farmers are able to obtain 54 percent of their potential profit from a unit mix of inputs. In other words, average farmer in the study area is fairly efficient in using available inputs and could increase their profit efficiency by $46 \%$ by improving their technical and allocative efficiency. This result is in consonance with the findings of Tsue et al. (2012) and Bamiro et al. (2013). The result (Table 3 ) also shows that the gamma value $(0.7272)$ was significant at $1 \%$ level indicating that $73 \%$ of the output variability of poultry farmers was due to disparities in profit efficiency. The significance of the sigma-squared at $5 \%$ in the two groups indicated a good fit and correctness of the specified assumption of the distribution of the composite error term. The estimate of cost of labour, cost of purchasing birds and cost of operating expenses (cost of drugs, transportation) was positive and significant. This implies that for a $10 \%$ increase in the cost of hired labour, cost of birds, and cost of operating expenses will results in an increase in profit efficiency by $5.399,1.484$ and $8.098 \%$ respectively. The coefficient for the cost of feed and water were negatively significant. This means that for a $10 \%$ increase in the cost of feed and water will result in a decrease in the profit efficiency by 0.289 and $0.187 \%$ respectively. This is in disagreement with the findings of Akaps and Odoemenem, (2018) that high cost of feed and water contributed positively to the value of output of smallscale poultry farmers.

\section{Poultry farmer's levels of profit efficiency}

The result presented in Table $3 \mathrm{~b}$ shows that the farm profit efficiencies range from 0.08 to 0.90 . The mean efficiency estimate among poultry farmers was 0.54 . The efficiency distribution also reveals that 72.00 percent of the farmers attained profit efficiency level between 41 and 70 . This

Table 3: Maximum likelihood estimates of the profit efficiency function

\begin{tabular}{|c|c|c|c|}
\hline Variables & Coefficient & Standard error & t-ratio \\
\hline $\begin{array}{l}\text { Ln normalized } \\
\text { cost of bird }\end{array}$ & $0.1485^{\star *}$ & 0.0607 & 2.44 \\
\hline $\begin{array}{l}\text { Ln normalized } \\
\text { cost of feed }\end{array}$ & $-0.2894^{\star *}$ & 0.1290 & 2.24 \\
\hline $\begin{array}{l}\text { Ln normalized } \\
\text { cost of labour }\end{array}$ & $0.5399^{* * *}$ & 0.0599 & 9.01 \\
\hline $\begin{array}{l}\text { Ln normalized } \\
\text { cost of water }\end{array}$ & $-0.1874^{\star \star}$ & 0.0862 & -2.17 \\
\hline $\begin{array}{l}\text { Ln normalized } \\
\text { cost of } \\
\text { operating } \\
\text { expenses }\end{array}$ & $0.8098^{\star * *}$ & 0.1726 & 4.69 \\
\hline Constant & $1.7876^{* * *}$ & 0.3395 & 5.26 \\
\hline Sigma-squared & 1.1253 & 0.2038 & 6.15 \\
\hline Gamma & 0.7272 & 0.0881 & 8.25 \\
\hline LR Test & 8.170 & & \\
\hline $\begin{array}{l}\text { Log-likelihood } \\
\text { ratio }\end{array}$ & -242.12 & & \\
\hline Mean & 0.5425 & & \\
\hline Standard dev. & 0.1577 & & \\
\hline
\end{tabular}


Table 3b: Distribution of respondents by their level of profit efficiency

\begin{tabular}{|l|c|c|}
\hline Profit efficiency index & Frequency & Percentage \\
\hline $0.01-0.10$ & 3 & 1.50 \\
\hline $0.11-0.20$ & 5 & 2.50 \\
\hline $0.21-0.30$ & 15 & 7.50 \\
\hline $0.31-0.40$ & 11 & 5.50 \\
\hline $0.41-0.50$ & 29 & 14.50 \\
\hline $0.51-0.60$ & 72 & 36.00 \\
\hline $0.61-0.70$ & 43 & 21.50 \\
\hline $0.71-0.80$ & 18 & 9.00 \\
\hline $0.81-0.90$ & 4 & 2.00 \\
\hline Total & 200 & 100.00 \\
\hline Mean & 0.5425 & \\
\hline Standard dev. & 0.1577 & \\
\hline
\end{tabular}

Source: Field survey (2019)

implies that poultry farmers are able to obtain $54 \%$ of their potential profit from a unit mix of inputs. In other words, average farmers in the study area are fairly efficient in using available inputs and could increase their profit efficiency by $46 \%$ by improving their technical and allocative efficiency. This result is in consonance with the findings of Tsue et al. (2012) and Bamiro et al. (2013).

\section{Determinant of the effect of microcredit on profit efficiency}

The results of the tobit regression are shown in Table 4. In model 1, the coefficient of amount of microcredit secured by poultry farmers had a positive relationship with profit efficiency and is statistically significant at $1 \%$ level. As poultry farmers secure adequate funding, it scales up their production and also enable them to invest in productivityenhancing technologies which in turns improve their profit efficiency. Achoja (2013) stated that microcredit could only leads to micro multiplier effect as it usually takes 5 years before poultry farmers could achieve $72 \%$ increase in their income. Adeoti (2003) and Kehinde and Olatidoye (2020) further submitted that credit-constraint farmers usually experience low productivity because merely having access to credit is not sufficient to improve productivity without the adequate amount of credit required to ensure sufficient working capital. The negative and significant coefficient of interest rate on profit efficiency is due to the fact that the profit that is meant for poultry production would have been paid inform of the interest on the loan borrowed. Loan repayment period had a positive relationship with profit efficiency and is statistically significant. Poultry production requires a substantial amount of start-up and running capital and it takes a longer period before the farmer can recover their initial invested capital. Findings from Samson and Obademi (2018) underscore the need for a longer loan repayment period to enhance the productivity of poultry farmers. Distance to microcredit source $(\geq 15 \mathrm{~km})$ is positive and significant. This implies that the distance between farmer's residence and the source of microcredit being greater than $15 \mathrm{~km}$ tends to increase the profit efficiency of their poultry farms. This is against the a priori expectation however, this may be because of the stress the farmers would have undergone before having access to substantial amount of microcredit outside their communities.

In the second model, the positive and significant coefficient of education indicates that years of education increases profit efficiency. This is in support of findings of Ibitoye and Onimisi (2013) who reported that formal education increases farmer's productivity and efficiency in poultry production but in contrary to Tibi and Adaigho (2015) who believed that the most educated farmers tend to migrate out of their communities in search for better employment which in turn leads to decrease in productivity. A positive and significant coefficient of experience and membership

Table 4: Estimates of a Tobit model on the effects of microcredit on profit efficiency

\begin{tabular}{|l|c|c|c|c|c|c|}
\hline Variable & Model I & & Model II & & Model III & \\
\hline Profit efficiency index & Coefficients & RSE & Coefficients & RSE & Coefficients & RSE \\
\hline Access to microcredit & 0.0230 & 0.0341 & - & & 0.0118 & 0.0333 \\
\hline Amount of microcredit & $5.79 \mathrm{e}-08^{* * *}$ & $1.97 \mathrm{e}-08$ & - & & $4.06 \mathrm{e}-08^{* *}$ & $2.06 \mathrm{e}-08$ \\
\hline Interest rate & $-0.0048^{* * *}$ & 0.0017 & - & & $-0.0048^{* * *}$ & 0.0017 \\
\hline Loan repayment period & $0.0051^{* *}$ & 0.0024 & - & & $0.0051^{* *}$ & 0.0023 \\
\hline Distance & $0.0451^{* *}$ & 0.0195 & - & & $0.0362^{* *}$ & 0.0181 \\
\hline Timeliness & -0.0245 & 0.0252 & - & & -0.0280 & 0.0281 \\
\hline Sex & - & & -0.0229 & 0.0251 & -0.0137 & 0.0233 \\
\hline Age & - & & 0.0005 & 0.0015 & -0.0003 & 0.0014 \\
\hline Household size & - & -0.0047 & 0.0055 & -0.0037 & 0.0052 \\
\hline Education & - & & $0.0062^{* * *}$ & 0.0016 & $0.0042^{* * *}$ & 0.0016 \\
\hline Main occupation & - & & 0.0245 & 0.0202 & 0.0193 & 0.0192 \\
\hline Farming experience & - & & $0.0052^{* * *}$ & 0.0017 & $0.0039^{* *}$ & 0.0016 \\
\hline Membership & - & & $0.0878^{* *}$ & 0.0365 & $0.0733^{* *}$ & 0.0364 \\
\hline Constant & $0.5005^{* * *}$ & 0.0199 & $0.3602^{* * *}$ & 0.0619 & $0.4059^{* * *}$ & 0.0616 \\
\hline Sigma & 0.1327 & 0.0077 & 0.1358 & 0.0078 & 0.1262 & 0.0071 \\
\hline F-statistics & $8.49^{* * *}$ & & $5.87^{* * *}$ & & $5.10^{* * *}$ & \\
\hline Pseudo R & -0.3680 & & -0.3320 & & -0.5469 & \\
\hline Log pseudolikelihood & 80.6645 & & 78.5419 & & 91.2088 & \\
\hline
\end{tabular}

${ }^{*},{ }^{* *},{ }^{* *}$ indicate statistical significance at the $10 \%, 5 \%$ and $1 \%$ alpha levels, respectively. The RSE means robust standard errors 
of cooperatives or association depicts that poultry farmers who have more experience and also belong to farmers/social association exhibit higher level of profit efficiency. This result is supported by the findings of Adedeji et al. (2014) that membership significantly increased farm level efficiency of poultry farmers and also Bamiro et al. (2013) reported that years of poultry farming experience increases the level of poultry farm efficiency.

The third model which combine the microcredit and socioeconomic variables shows the same significant variables as model 1 and 2. Nevertheless, from the three models, it can be concluded from the F-statistics that microcredit variables were the most important and leading variables affecting profit efficiency of farmers. This implies that size/amount of microcredit obtained by poultry farmers, interest rate paid on loan acquired, loan repayment period and distance from farmers' resident to lending source were the important variables that affect the level of the profit efficiency of smallscale poultry farmers in the study area.

\section{CONCLUSIONS AND POLICY RECOMMENDATIONS}

The study investigated the effect of microcredit on the profit efficiency of small-scale poultry farmers in Oyo State, Nigeria. The study concluded that majority of poultry farmers are male, small scale, literate and at economic active age. Evidence from the study further showed that majority of farmers interviewed had access to microcredit. The average microcredit amount obtained by farmers in the study area was \#47,670.00 and cooperative accounted for the most sourced of microcredit among farmers. The result of the probit model indicated that access to microcredit is significantly related to membership of farmer's organization and extension contact. The estimates of the second stage of the Heckman analysis reveals that age, level of education, household size, farming experience, distance to the sources of microcredit, timeliness of microcredit and stock size were the significant factors influencing the size/amount of microcredit obtained by small scale poultry farmers. The study also found that the mean profit efficiency in the area of study is 0.54 . In the second step analysis, the relationship between profit efficiency, microcredit variables and socioeconomic attributes of farmers was investigated. This stage relied on two limit tobit regression methods to estimate the three separate equations. The analysis showed that profit efficiency of farmers increases with an increase in the amount of microcredit obtained, longer loan repayment period, level of education, membership of an association and farming experience. To increase profit efficiency, the study recommends that there should be an increment in the size of microcredit provided for farmers with longer loan repayment period. From the policy viewpoint, it should be noted from the F-statistics that microcredit variables are the most favourable variables for line of action. Policy makers should therefore ensure that the microcredit made available through the agricultural credit programmes get to the needy farmers and microcredit made available through banks should not have stringent procedures as these processes usually take longer time and discourage farmers from accessing microcredit. Also, for poultry farmers to be financially solvent, there should be an improvement in their level of education and extension agents should be mobilized to sensitize and educate poultry farmers periodically on available sources of microcredit in their vicinities.

\section{REFERENCES}

1. Adedeji, O.S., Amao, S.R., Alabi, T.J., \& Opebiyi O.B. (2014). Assessment of poultry production system in Ilesha West Local Government Area of Osun State, Nigeria. Scholars Journal of Agriculture and Veterinary Sciences, 1(1), 20-27.

2. Adeoti, A.I. (2003). The impact of credit on poultry farm productivity in Oyo State, Nigeria. Tropical Journal of Animal Science, 6(2), 47-51.

3. Adesiyan, O.I. (2014). Technical Efficiency of Poultry Production in Afijio Local Government Area of Oyo state, Nigeria. Developing Country Studies, 4(20), 23-34.

4. Adeyonu, A., Ajiboye, B., Isitor, S., \& Faseyi, S. (2017). An analysis of the factors influencing access to credit by poultry farmers in Abuja, Nigeria. Agriculturae Conspectus Scientificus, 8(1), 55-62.

5. Agbaeze, E.K., \& Onwuka, I.O. (2014). Impact of microcredit on poverty alleviation in Nigeria - the case of Enugu East Local Council. International Journal of Business and Management Review, 2(1), 27-51.

6. Akanni, I.A. (2007). Effect of micro-Finance on small scale poultry business in South Western Nigeria. Journal of Food and Agriculture, 19(2), 38-47.

7. Akaps, J.H., \& Odoemenem, U.I (2018) Effects of microcredit on productivity of small scale poultry farmers in Kaduna Central Agricultural Zone, Kaduna State, Nigeria. Journal of Economics and Sustainable Development, 9(18), 226-355.

8. Akintunde, O.K., \& Adeoti, A.I. (2014). Assessment of factors affecting the level of poultry disease and management in Southwest, Nigeria. Trends in Agricultural Economics, 7, 41-56.

9. Anang, B.T., Sipiläinen, T., Bäckman, S., \& Kola, J. (2015). Factors influencing smallholder farmers' access to agricultural microcredit in Northern Ghana. African Journal of Agricultural Research, 10(24), 2460-2469.

10. Anyiro, C.O. (2015). Access to and investment of formal micro credit by small holder farmers in Abia state, Nigeria. A case study of ABSU micro finance bank, Uturu. The Journal of Agricultural Sciences, 6(2), 70-76.

11. Bamiro, M.O., Otunaiya, A.O., \& Adejumo, I.O. (2013). Profit efficiency in poultry production in periurban Lagos, Nigeria. International Journal of Applied Agricultural and Apicultural Research, 1(2), 120-130.

12. De Young, R. \& Hassan, I. (1998). The performance of De Novo commercial banks: A profit efficiency approach. Journal of Banking and finance, 22(5), 565-589.

13. Enimu, S., Bassey, J.I., \& Eyo, E.O. (2018). Determinants of borrowing capacity of small holder farmers in Cross River State, Nigeria. Journal of Business and Financial Affairs, 7(1), 1-4. doi: 10.4172/2167-0234.1000311

14. Ewubare, D.B., \& Ozar, V. (2018). Effect of poultry 
production on agricultural production in Nigeria. Economy, 5(1), 8-16.

15. Gbigbi, T.M. (2017). Measurement of profit efficiency among broiler producers in Delta State, Nigeria. African Journal of Agriculture, Technology and Environment, 6(2), 64-74.

16. Haile, M. (2014). The determinants of profit efficiency of coffee producing and marketing cooperatives: The case study of Sidama coffee farmers' union. Journal of Economics and Sustainable Development, 5(7), 125-137.

17. Heckman, J.J. (1979). Sample selection bias as a specification error. Econometrical, 47, 153-161.

18. Ibitoye, S.J., \& Onimisi, J.A. (2010). Economic assessment of yam production in Kabba-Bunu Local Government Area of Kogi State, Nigeria. Journal of Development and Agricultural Economics, 5(1), 470-475.

19. Ibrahim, A.H., \& Bauer, S. (2013). Access to micro credit and its impact on farm profit among rural farmers in dryland of Sudan. Global Advanced Research Journal of Agricultural Science, 2(3), 088-102.

20. Kehinde, A.D., \& Olatidoye, M.S. (2020). Credit Constraint and Technical Efficiency of Smallholder Cassava Farmers in Osun State, Nigeria. Agricultura, 16(1-2), 27-33.

21. Nor, H.A., \& Mohamad, A.N. (2011). The determinants efficiency and profitability of world Islamic banks. International conference on E-business, Management and Economics, 3, 229-231.

22. Olagunju, F.I. (2010). Impact of credit on poultry productivity in Southwestern Nigeria. World Rural Observations, 2(4), 29-37.

23. Olagunju, F.I., \& Babatunde, R.O. (2011). Impact of credit on poultry productivity in south-western Nigeria. Journal of Agricultural and Biological Science, 6(10), 5865.

24. Ologbon, O.A., \& Ambali, O.I. (2012). Poultry enterprise combination among small scale farmers in Ogun State, Nigeria: A technical efficiency approach. Journal of Agricultural and Veterinary Science, 4, 7-15.

25. Oshinowo, O.Z., Muyiwa, A., Olawale, O., \& Olanrewaju, O. (2017). Monitoring impact analysis of microfinance institutions on rural households wellbeing in Oyo State: A case study of ifad/rufin supported project final draft report.

26. Prince, C.N., Ikechukwu, S.N., \& Godfrey, O.O. (2014). From rural to microfinance banking: Contributions of micro credits to Nigeria's economic growth - An ARDL approach. International Journal of Financial Research, 5(3), 73-85.

27. SAHEL, (2015). An assessment of Nigerian poultry sector. Sahel capital partners \& advisory limited, 11.

28. Samson, A., \& Obademi, O. (2018). The determinants and impact of access to agricultural credit on productivity by farmers in Nigeria: Evidence from Oyo State, Nigeria. Advances in Social Sciences Research Journal, 5(3), 252-265.

29. Tibi, K.N., \& Adaigho, D.O. (2015). Impact of microfinance on small-scale poultry production in Delta State, Nigeria. Journal of Agriculture and Veterinary Science, 8(2), 01-07.
30. Tijani, A.A., Alimi T., \& Adesiyan, A.T. (2006). Profit efficiency among Nigerian poultry egg farmers. Research Journal of Agricultural and Biological Sciences, 2(6), 256261.

31. Tobin, J. (1958). Estimation of relationship for limited dependent variables. Economerica, 26(1), 24-36.

32. Tsue, P.T., Lawal, W.L., \& Ayuba, V.O. (2012). Profit efficiency among catfish farmers in Benue State, Nigeria. African Journal of Food, Agriculture, Nutrition and Development, 12(6), 6759-6775. 


\section{Vpliv mikroposojil na dobičkonosnost malih rejcev perutnine v Oyo State, Nigerija}

\section{IZVLEČEK}

Cilj raziskave je bil preučiti vpliv mikroposojil na dobičkonosnost malih rejcev perutnine v Oyo State (Nigerija). Vzorec 200 rejcev perutnine za raziskavo so izbrali $\mathrm{z}$ večstopenjskim postopkom vzorčenja. Zbrane podatke so analizirani z uporabo opisne statistike, Heckmanovega izbirnega modela, stohastičnim modelom in Tobitovim modelom. Rezultati, dobljeni z opisno statistiko so pokazali, da so v prirejo perutnine pretežno vključeni moški (78\%), stari v povprečju 43 let, večinoma poročeni (77,5\%) in tudi pismeni (80,5\%). Večina anketirancev (73,5\%) je imela dostop do mikroposojil, pri čemer jih je bilo 87,5\% vključenih v različna združenja kmetov. Heckmanov dvostopenjski model izbire je pokazal, da sta članstvo v zadružnem (kmetijskem) združenju in stik s svetovalcem pomembna dejavnika, ki vplivata na dostop kmeta do mikroposojila. V drugi stopnji modeliranja se je izkazalo, da so starost, izobrazba, velikost gospodinjstva, delovne izkušnje, oddaljenost do vira financiranja, pravočasnost prijave za posojilo in velikost kmetije pomembni dejavniki, ki vplivajo na znesek mikroposojila. Rezultati, dobljeni s stohastičnim modelom, so pokazali, da so imeli mali perutninarji pri proizvodnji perutnine v povprečju 54\% stopnjo dobičkonosnosti. Nadalje so rezultati prvega Tobitovega modela razkrili, da so višina mikroposojila, oddaljenost od vira financiranja, obrestna mera in obdobje odplačevanja posojila pomembno vplivale na dobičkonosnost, v drugem modelu pa so se kot pomembni vplivi na dobičkonosnost izkazali leta formalnega izobraževanja, izkušnje s perutninarstvom in članstvo v zadružnih/kmetijskih zvezah. Na osnovi rezultatov avtorji političnim odločevalcem predlagajo, da zagotovijo, da mikroposojila, ki so na voljo v okviru kmetijskih programov, pridejo do kmetov, ki ta posojila potrebujejo glede na predstavljene rezultate.

Ključne besede: mikroposojilo, dobičkonosnost, perutninarstvo, mali kmetje, Oyo State 